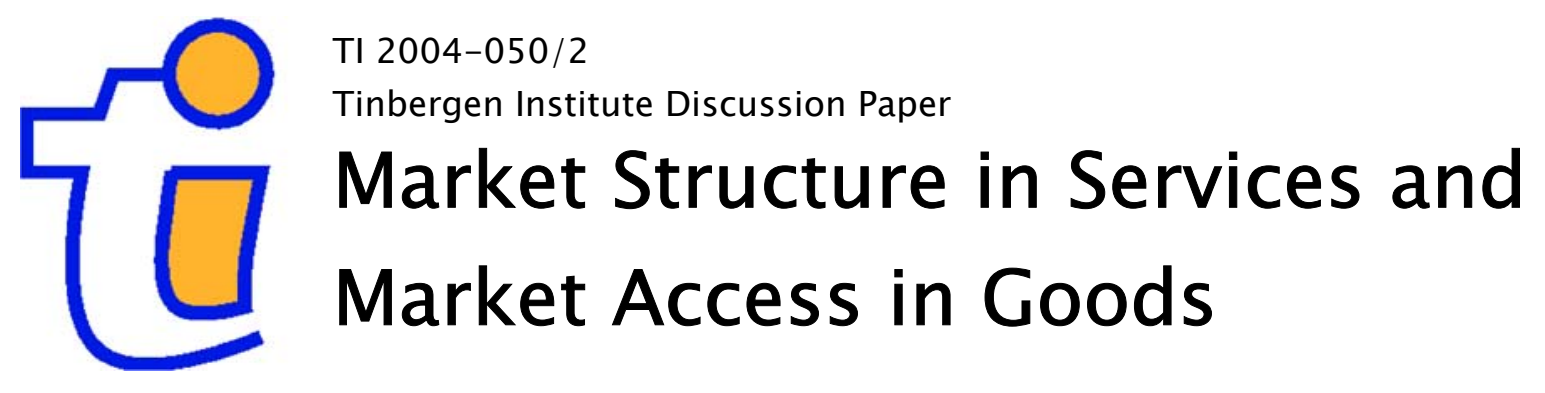

Joseph Francois'

Ian Wooton ${ }^{2}$

${ }^{1}$ Department of Economics, Erasmus Universiteit Rotterdam, Tinbergen Institute, and CEPR, 2 Strathclyde University, and CEPR. 


\section{Tinbergen Institute}

The Tinbergen Institute is the institute for economic research of the Erasmus Universiteit Rotterdam, Universiteit van Amsterdam, and Vrije Universiteit Amsterdam.

Tinbergen Institute Amsterdam

Roetersstraat 31

1018 WB Amsterdam

The Netherlands

Tel.: $\quad+31(0) 205513500$

Fax: $\quad+31(0) 205513555$

Tinbergen Institute Rotterdam

Burg. Oudlaan 50

3062 PA Rotterdam

The Netherlands

Tel.: $\quad+31(0) 104088900$

Fax: $\quad+31(0) 104089031$

Please send questions and/or remarks of nonscientific nature to driessen@tinbergen.nl.

Most TI discussion papers can be downloaded at http://www.tinbergen.nl. 


\title{
Market Structure in Services and Market Access in Goods
}

\author{
Joseph Francois \\ Tinbergen Institute (Rotterdam) and CEPR \\ Ian Wooton \\ Strathclyde University and CEPR
}

May 2004

\begin{abstract}
We examine interaction between trade in goods and market power in domestic trade and distribution, developing a model that highlights this interaction. Theory points to an expected linkage between service sector competition and goods trade, one supported by econometrics involving import patterns of 21 OECD countries vis-à-vis 86 trading partners. This points to significant linkages between effective market access conditions for goods and the structure of the service sector. Because of the implied interaction, ignoring the structure of the domestic service sector may lead to a substantial underestimation of the direct impact of tariffs on trade flows.
\end{abstract}

JEL Codes: F12, F13, F23

Keywords: market access, services trade, trade liberalization, competition policy, imperfect competition, GATS 


\section{MARKet Structure in SERvices ANd MARKet ACCESS in GoOdS}

Abstract: We examine interaction between trade in goods and market power in domestic trade and distribution, developing a model that highlights this interaction. Theory points to an expected linkage between service sector competition and goods trade, one supported by econometrics involving import patterns of 21 OECD countries vis-à-vis 86 trading partners. This points to significant linkages between effective market access conditions for goods and the structure of the service sector. Because of the implied interaction, ignoring the structure of the domestic service sector may lead to a substantial underestimation of the direct impact of tariffs on trade flows.

JEL Codes: F12, F13, F23

Keywords: market access, services trade, trade liberalization, competition policy, imperfect competition, GATS

\section{INTRODUCTION}

In this paper, we are concerned with the relationship between the traditional concept of market access in goods sectors and the degree of competition in the service sector. In particular, we examine the interaction between trade in goods and the degree of competition in the "margin" services that facilitate the interaction between producers and exporters in one country and final consumers in another. This includes domestic shipping and logistic services, of course, as well as the wholesale and retail sectors and other links in the distribution chain that carries imported goods to the consumer.

By exploring these issues, we examine an important but somewhat ignored aspect of the trading system. In the European Union, for example, internal trade in motor vehicles has been hampered by an antitrust exemption for the distribution and servicing of automobiles. (See both Flam and Nordstrom 1995, and Lutz, forthcoming). Access to the distribution system was also at the heart of a dispute between the United States and Japan involving Kodak and Fuji film (Nanto 1998). These issues also lurk behind the retail distribution system and its impact on trade in both Switzerland and Japan, and behind the German experience with retailing cartels (and the threat of foreign retail entry to established domestic players). With the elimination of trade barriers for textile and clothing under the WTO's Agreement on Textiles and Clothing in 2005, the market power of buyers like Wal-Mart may also be 
an important in the transmission of price and quantity changes across global textile and clothing markets.

In general, international trade in goods depends on the domestic trade and distribution sector that facilitates this trade. We focus here on the degree of competition in the domestic distribution sectors, and the impact on trade in goods. This includes an assessment of linkages between service sector competition and the value of negotiated market access concessions. We proceed in this paper as follows. In Section 2 we develop a basic analytical model, involving a domestic distribution sector with market power. We work with this model to examine the impact of imperfect competition in services for the pattern of trade in goods. In Sections 3 and 4 then examine the impact on gains from trade for both importers and exports. In Section 5 we work with data on competition in distribution and sales in several OECD countries, econometrically examining the interaction between import protection, competition, and the pattern of trade. We offer concluding comments in Section 6.

\section{BASIC MODEL}

We consider the market for imports of a homogeneous good. The domestic government taxes imports that are supplied by competitive firms. Our focus is on the domestic sale and distribution network. We assume this sector to be less-thanperfectly competitive. Thus we shall be focus on the interactions between three sets of agents: the government, consumers, and the distributors.

\section{Import supply}

The home country imports a good that is supplied by competitive, overseas producers. The export supply schedule is imperfectly elastic. Consequently, the importing country has some degree of monopoly power in trade. It subjects trade in these goods to an import tax at rate $\tau$. This creates a wedge between the cif price $P$ and the landed (that is, after duties are paid) price $P^{L}$. Let the total quantity imported be $q$. Then the inverse supply function is:

$$
P=S(q) \quad S^{\prime}>0
$$

while landed prices are: 


$$
P^{L}=P \cdot T \quad T=(1+\tau)
$$

\section{Import demand}

Consumer demand for the imported good is assumed to be inversely related to price.

Let $P^{d}$ be the final demand price, where the inverse demand curve is:

$$
P^{d}=D(q) \quad D^{\prime}<0
$$

\section{The intermediation sector}

Interaction between the exporter and the final consumer is assumed to require the services of a domestic service sector that facilitates both the movement of imported goods inland, and also the wholesale and retail distribution, marketing, and any ancillary services required to sell the goods. These services are supplied by a domestic service cartel (Cournot oligopoly) at constant marginal cost.

The total revenue of a representative firm $i$ in the service sector is:

$$
T R_{i}=D(q) \cdot q_{i}
$$

where $q_{i}$ is the quantity sold by a representative intermediary firm $i$. We further assume that there are $n$ identical firms in the market, each having a share $\Omega=n^{-1}$. It is useful to think of $\Omega$ as an index of market competitiveness that ranges from a value of zero, under perfect competition $(n=\infty)$, to a value of one, when a single firm monopolizes distribution ( $n=1$ ) or, alternatively, an oligopolistic service sector acts as a monopolist through perfect collusion in a cartel.

Assuming a constant marginal cost $c$, firm profit is defined as follows:

$$
\pi_{i}=D(q) \cdot q_{i}-\left(T \cdot S \cdot(q)+c_{i}\right) \cdot q_{i}
$$

Profit maximization then requires the following condition to hold.

$$
d \pi_{i} / d q_{i}=\left(D(q)-T \cdot S(q)-c_{i}\right)-q_{i} \cdot\left(T \cdot S^{\prime}-D^{\prime}\right) \cdot \partial q / \partial q_{i}=0
$$


If we apply the set of standard Cournot-Nash assumptions, including quantity competition and symmetry, and defining supply and demand elasticities as $\varepsilon^{s}$ and $\varepsilon^{d}$ then equation (6) can be rearranged to yield the usual perceived $M R_{i}=M C_{i}$ condition:

$$
D(q) \cdot\left(1+\frac{\Omega}{\varepsilon^{d}}\right)=S(q) \cdot T \cdot\left(1+\frac{\Omega}{\varepsilon^{s}}\right)+c
$$

From equation (7), distribution firms have market power on both sides of the market. On the cost side, the price they pay for the imported good depends upon the total quantity $q$ and the sensitivity of supply to quantity. Similarly, on the demand side, the price at which they sell to consumers is a function of total quantity brought to market. By restricting their trading, the firms are able to both drive down costs and drive up prices, widening the price-cost margin and raising profits.

Differentiating equation (7) with respect to market power, and assuming that elasticities are (locally) constant, we can obtain the response of equilibrium quantities to tariffs and market power.

$$
\begin{aligned}
& D(q) \cdot\left(1+\frac{\Omega}{\varepsilon^{d}}\right)=S(q) \cdot T \cdot\left(1+\frac{\Omega}{\varepsilon^{s}}\right)+c \\
& D^{\prime} \cdot\left(1+\frac{\Omega}{\varepsilon^{d}}\right) \cdot d q+D(q) \cdot \frac{d \Omega}{\varepsilon^{d}}=T \cdot S^{\prime} \cdot\left(1+\frac{\Omega}{\varepsilon^{s}}\right) \cdot d q+S(q) \cdot T \cdot \frac{d \Omega}{\varepsilon^{s}} \\
& {\left[D^{\prime}\left(1+\frac{\Omega}{\varepsilon^{d}}\right)-S^{\prime} \cdot T\left(1+\frac{\Omega}{\varepsilon^{s}}\right)\right] d q=\left[\frac{S(q)}{\varepsilon^{s}}-\frac{D(q)}{\varepsilon^{d}}\right] \cdot d s} \\
& \frac{d q}{d \Omega}=\left[\frac{S(q)}{\varepsilon^{s}}-\frac{D(q)}{\varepsilon^{d}}\right] \cdot\left[D^{\prime}\left(1+\frac{\Omega}{\varepsilon^{s}}\right)-S^{\prime} \cdot T \cdot\left(1+\frac{\Omega}{\varepsilon^{d}}\right)\right]^{-1}<0 \\
& D(q) \cdot\left(1+\frac{\Omega}{\varepsilon^{d}}\right)=S(q) \cdot T \cdot\left(1+\frac{\Omega}{\varepsilon^{s}}\right)+c \\
& D^{\prime}\left(1+\frac{\Omega}{\varepsilon^{d}}\right) \cdot d q=S^{\prime} \cdot T \cdot\left(1+\frac{\Omega}{\varepsilon^{s}}\right) \cdot d q+S(q) \cdot\left(1+\frac{\Omega}{\varepsilon^{d}}\right) \cdot d T \\
& d q / d T=\left[D^{\prime}\left(1+\frac{\Omega}{\varepsilon^{d}}\right)-S^{\prime}\left(1+\frac{\Omega}{\varepsilon^{s}}\right)\right] \cdot\left[S(q) \cdot\left(1+\frac{\Omega}{\varepsilon^{d}}\right)\right]^{-1}<0
\end{aligned}
$$


What is the interaction between tariffs and market power? Differentiating equation (8) with respect to T yields equation (10):

$$
\frac{d^{2} q}{d \Omega d T}=\left[\frac{S(q)}{\varepsilon^{s}}-\frac{D(q)}{\varepsilon^{d}}\right] \cdot\left[D^{\prime}\left(1+\frac{\Omega}{\varepsilon^{s}}\right)-S^{\prime} \cdot T \cdot\left(1+\frac{\Omega}{\varepsilon^{d}}\right)\right]^{-2}\left[S^{\prime} \cdot\left(1+\frac{\Omega}{\varepsilon^{d}}\right)\right]>0
$$

Equations (8)-(10) yield the following properties for the implicit function defining equilibrium quantity.

$$
q=Q(\Omega, T) \quad Q_{\Omega}, Q_{T}<0 \quad Q_{\Omega T}>0
$$

In the special case of linear demand and supply curves, where $S(q)=a+b q$ and $D(q)=x-y q$ equation (11) can be written explicitly as follows (see the annex).

$$
q=\frac{x-T a-c}{(1+\Omega) \cdot(y+T b)}
$$

From equations (10) and (11), we make the following observations:

Observation 1: International trade volumes are inversely related to the degree of concentration in the domestic trade and distribution sector, or alternatively the degree of market power exercised in the domestic sector. (Equation 11)

Observation 2: The negative impact of market power on trade volumes is greatest in a zero tariff context, and its marginal impact falls with increased levels of trade. Hence, the largest impact will be observed in zero-tariff countries, free trade areas, and customs unions. (Equation 10)

\section{TARIFFS AND THE GAINS FROM TRADE}

We focus next on the welfare implications of a range of alternative tariff regimes for the importer, and the roles played by competition across this range. For the importing 
country, the gains from trade include three components. These are profits, tariff revenue, and consumer surplus.

Profits are obtained by combining equations (5) and (11). Starting from free trade as a benchmark, this also allows us to define the impact of a tariff on profit $\Delta \pi$.

$$
\begin{aligned}
& \pi=D(Q) \cdot Q-(T S(Q)+c) Q \\
& \frac{d \pi}{d T}=\left[D\left(\frac{1+\varepsilon^{d}}{\varepsilon^{d}}\right)-T S\left(\frac{1+\varepsilon^{s}}{\varepsilon^{s}}\right)-c\right] Q_{T}-S(Q) \cdot Q<0
\end{aligned}
$$

In equation (14), the first term in brackets is second order, relating to the impact of tariffs on unit margins. This will be outweighed by the second term for any reasonable set of values, as the second term represents the full value of imports, and hence the first-order impact of a tariff increase on costs. Not surprisingly then, increased tariffs lead to a fall in profits.

Turning next to consumer surplus, we can derive this by integration of equation (3), and on focusing on the region between the final demand price and the inverse demand curve. Starting from free trade as a reference point, we can also then define the change in consumer surplus $\Delta C S$ implied by the introduction of a tariff.

$$
\begin{aligned}
C S \quad & =\int_{0}^{q_{0}}\left(D(q)-D\left(q_{0}\right)\right) \cdot d q \\
\Delta C S \quad & =\int_{0}^{q_{1}}\left(D(q)-D\left(q_{1}\right)\right) \cdot d q-\int_{0}^{q_{0}}\left(D(q)-D\left(q_{0}\right)\right) \\
& \approx\left(-q_{1}+\frac{1}{2}\left(q_{1}-q_{0}\right)\right) \cdot\left[D\left(q_{1}\right)-D\left(q_{0}\right)\right]
\end{aligned}
$$

Finally, tariff revenue is also defined by employing equation (11).

$$
\begin{aligned}
T R & =P \cdot(T-1) \cdot Q(T, S) \\
& =S(q) \cdot(T-1) \cdot Q(T, S)
\end{aligned}
$$

We can now examine the impact of a tariff on welfare, starting with free trade as our benchmark. 


$$
\begin{aligned}
\Delta W= & \Delta \pi+\Delta C S+\Delta T R \\
= & {\left[1 / 2\left(Q_{1}-Q_{o}\right)\left(D\left(Q_{1}\right)-D\left(Q_{0}\right)\right)\right] } \\
& \quad+\left(D\left(Q_{1}\right)-S\left(Q_{1}\right)-c\right) Q_{1}-\left(D\left(Q_{0}\right)-S\left(Q_{0}\right)-c\right) Q_{0}
\end{aligned}
$$

The basic welfare calculus depends on the trade-off between net efficiency losses on the one hand as represented by the Harberger triangle term in square brackets in equation (14), and the terms-of trade gains on the other hand, as represented by changes in the spread between consumer price and the world price. In a competitive market, this would be captured as part of tariff revenue. With imperfect competition, this is instead shared between government (as tariffs) and intermediaries (as profits). For the welfare calculus, the critical issue remains simply the cumulative terms-oftrade gain, weighed against efficiency losses in consumption.

We illustrate the implied welfare mechanics for an importer in Figure 1, based on the linear case developed in the appendix. It is straightforward in this case to show the tariff that maximizes aggregate welfare when the service industry is competitive, as this is the conventional optimal tariff that fully exploits the country's trade power with respect to the exporting nation. As the service sector is making no profits, the only distortion in the market, from the home country's point of view, is its unexploited monopoly power in trade. This is corrected by the imposition of $t^{*}$ as shown in the figure. ${ }^{1}$

It is when there is an additional distortion in the market, in the form of an imperfectly competitive distribution sector, that the welfare implications of trade policy become more complicated. (We assume for illustration that the domestic intermediation sector is wholly domestically owned.) The contours in Figure 1 show the various levels of welfare that can be achieved through the choice of tariff for any level of service-sector concentration, from competition to monopoly.

In perfect competition, $t^{*}$ maximizes welfare. It is evident that the optimal tariff declines with increasing concentration in services. Indeed, the optimal tariff when the service sector is a monopoly is a subsidy. The more concentrated the service sector, the greater its exercise of its market power and, consequently, the lower the trade volume. A tariff further reduces the volume of trade, whereas a subsidy

\footnotetext{
${ }^{1}$ The underlying algebra for the numerical simulations shown in Figures 1 and 2 is shown in the annex. For the simulations in Figure $1, t^{*}=1 \cdot 265$, while the value of the optimal subsidy under monopoly is $0 \cdot 8953$.
} 
increases the level of imports and hence consumption. Such a subsidy benefits the service sector but, as their profits are part of national welfare, a welfare maximizing government would be prepared to offer it. ${ }^{2}$ In the setting under consideration, the trade volume, consumer surplus and aggregate domestic welfare are the same irrespective of whether the government or the service industry is optimally exploiting the country's monopoly power in trade. The only difference that arises is in the distribution of income between the government and the service sector.

Continuing with our numeric example, the impact of a tariff on the various components of welfare and on aggregate welfare is illustrated in Figure 2, where the service industry is now assumed to be a duopoly ( $s=0.5)$. As would be expected, consumer surplus declines monotonically with an increasing tariff, while tariff revenue increases to a maximum and then falls. Consequently, for national welfare, there is an interior solution for the optimal tariff, indicated by $t^{Z}$. If the service rents are excluded (in the case of foreign ownership for example), the optimal tariff is greater as indicated by $t^{W}$. The government, in exercising its monopoly power in trade, has the ability to limit the ability of the service sector to extract rents. When these rents accrue to domestic agents, the government will wish to moderate its use of the tariff.

We summarize the relationship between tariffs, profits, trade, and welfare in the following observations:

Observation 3: The optimum import tariff is a decreasing function of the degree of market power exercised in the domestic trade and distribution sectors (Figure 1 and equation 18).

Observation 4: The optimum markup for the domestic trade and distribution sectors is a decreasing function of the underlying import tariff. (Equation A8).

\footnotetext{
${ }^{2}$ The government can use other domestic instruments to redistribute income away from the service firms.
} 


\section{MARKET ACCESS AND THE EXPORTER}

Consider the impact of alternative tariff and competition regimes for the exporter. If we are focused on quantity alone, then equations (11) and (12) point to a direct negative relationship between tariffs and imperfect competition, on the one hand, and export volumes on the other. In addition, from equation (10), the trade volume effect of a tariff reduction depends on the underlying degree of competition in the domestic distribution sector. To some extent, tariff reductions may simply lead to a greater exercise of market power by the domestic distribution sector, nullifying expected direct benefits from tariff reductions in export markets.

A second measure of the benefits of improved market access conditions is exporter producer surplus $P S$. From equations (1) and (11), this can be found by making substitutions and integrating to find the area between the inverse supply curve and the export price. This also allows us to calculate the welfare benefit of improved market access as manifested through changes in export quantities from $q_{0}$ to $q_{1}$.

$$
\begin{aligned}
P S & =\int_{0}^{q_{0}}\left(S\left(q_{0}\right)-S(q)\right) \cdot d q \\
\Delta P S & =\int_{0}^{q_{0}}\left(S\left(q_{1}\right)-S(q)\right) \cdot d q-\int_{0}^{q_{p}}\left(S\left(q_{0}\right)-S(q)\right) \\
& \approx \int_{q_{0}}^{q_{0}}\left(S\left(q_{0}\right)-S(q)\right) \cdot d q+\left[S\left(q_{1}\right)-S\left(q_{0}\right)\right] \cdot q_{0}
\end{aligned}
$$

Producer surplus is driven by the perceived export demand curve, which in turn is determined by both the underlying tariff and the degree of exercised market power of the domestic trade and distribution sector in its export market. Consider the benefit of improved market access through tariff reduction. From equation (19), this is equal to the change in producer surplus as measured by the area between the export supply curve and the export price $P$. This in turn is a function of the realized change in export volumes. The greater the export effect, the greater the market access gains. From equation (11), the impact of a tariff on welfare is therefore a function of the degree of market power. We summarize this section with the following observations. 
Observation 5: The market access benefits of tariff reductions in export markets are inversely related to the degree of market power exercised by the domestic trade and distribution sector in the export market.

Observation 6: The benefits of past market access concessions can be offset by future increases in the degree of market power exercised by the domestic trade and distribution sector in the export market.

\section{EMPIRICS}

We turn next to a short empirical exercise. This involves estimating reduced form gravity equations of bilateral trade flows, based on tariffs, transport costs, and country-specific effect variables. (See Feenstra 2004, Chapter 5, and Hummels 1999). We include measures of distribution sector competition, as a check on our theoretical results.

Our basic data for this exercise are summarized in Table 1. From the OECD (2000), we have estimates of the degree of competition in the road freight and retail distribution for some, but not all, OECD members. This includes an index of barriers to entry in the sector, an index of price flexibility, and what can be interpreted as an overall or composite index of the degree of competition in the sector. These estimates are a one-off, in that we only have a single set for of indexes for the late 1990s. For trade, we work with bilateral merchandise trade data extracted from the GTAP6.2 database (GTAP 2004). These data are for 2001. They offer the advantage of including both a bottom-up concordance from detailed tariff data to aggregate bilateral trade flows, and also including estimates of bilateral transport cost margins. For the 86 countries and regional groupings, we have matched bilateral imports by the OECD countries covered by the OECD indexes on the distribution and freight sectors. Finally, we also include data on importer GDP and GDP per capita, from the World Bank (2002). After matching trade data to our competition data, we have 1,847 pairs of bilateral trade flows involving OECD imports in 2001.

Our estimating equation is a reduced-form gravity equation, augmented to reflect Observations 1 and 2 and equations (10) and (11). Since we are working with a single year, we impose a price normalization, with fob prices set at unity. Value 
flows then map to quantities. Defining imports by country $i$ from country $j$ as $M_{i j}$, we work with the following equation.

$$
\begin{aligned}
M_{i, j}=\alpha_{0}+ & \alpha_{1} \ln \left(G D P_{i}\right)+\alpha_{2} \ln \left(P C I_{i}\right)+\alpha_{3} \ln \left(T_{i, j}\right) \\
& +\alpha_{4} \ln \left(\Gamma_{i, j}\right)+\alpha_{5} \ln \left(\text { Index }_{i}\right)+\alpha_{6} \ln \left(\text { Index }_{i}\right) * \ln \left(T_{i, j}\right) \\
& +\sum_{j} \alpha_{7, j} D_{j}+\alpha_{8} \text { AAFTA }_{i, j}+\alpha_{9} E E A_{i, j}+\varepsilon_{i, j}
\end{aligned}
$$

The $D_{j}$ terms are dummy variables assigned to each exporter, to reflect the set of exporter-specific variables that remain fixed across importers. The variables NAFTA and $E E A$ are also dummies, capturing joint membership in either the North American of European free trade block. The terms $\Gamma$ and $T$ measure bilateral transport costs and import tariffs (trade-weighted) as a share of total import value. We expect the coefficients applied to these variables, $\alpha_{3}$ and $\alpha_{4}$ to both be negative. Recall that the Index term is meant to capture, at least qualitatively, the effects related to $\Omega$ in the discussion above. From equation (8), we expect $\alpha_{5}$ to be negative as well, while the interaction term $\alpha_{6}$ should be positive, from equation (10).

Table 2 presents regression results for equation (21), based on all three version of our competition index. Country fixed-effect coefficients are not shown, though they are all generally significant at the .001 level across all regressions. The first point to note is that the competition coefficients both have the expected sign with the OLS regressions, and they are also generally significant and the .05 or .01 level. (In applying a one-tailed test given out expectations about sign, the interaction term for the first competition index is also significant at the .05 level). Basically, the results suggest that tariffs and reduced competition both have a dampening effect on estimated trade flows. In addition, they interact as the theory developed above predicts.

While the OLS results look promising, on further examination of the error structures it becomes clear that the underlying OLS assumptions about the error term are simply wrong. Table 2 also reports the results of two tests for heteroscedasticity. The Breusch-Pagan(1979) Chi-squared test statistic (as implemented in STATA) leads us to reject the hypothesis of homoscedasticity at any conceivably reasonable level of significance. Further examination with Szroeter's (1978) test statistic (a 
recent STATA addition) points to a pervasive problem, involving roughly half of the right hand side variables. Most of these relate to the exporter fixed effect variables, indicating for example greater variance in the data involving some exporting countries than others. This is not surprising, as we have included relatively small aggregate trade flows (all flows over \$1million), usually involving a range of developing countries. $^{3}$ In these cases, bilateral trade flows may be a function of historical/structural variables unique to a given country pairing. Given the pervasiveness of the problem, there is a not an obvious single adjustment to be made to the data. We therefore resort to robust least squares, involving Huber's (1981) robust regressions as implemented in STATA. These results are shown in Table 2 as well. The pattern is the same as the OLS results, only with greater significance for the first competition index, but overall with the same qualitative pattern of results. All relevant coefficients are highly significant, and with the expected sign on the basis of equations (8)-(11) above.

One interesting implication of the relationship indicated by the coefficient $\alpha_{6}$ and by equation (10) is that variation in the degree of competition will interact with the impact of variations in import tariffs on trade patterns. Indeed, since some of the variable impact of competition will be offset by the adjustment of margins by distribution sectors, leaving out the competition measures means that we can expect to then underestimate the direct impact of tariffs on trade. To check this, we have re-run our estimation of equation (21), but without the inclusion of the competition variables. The resulting estimate of the direct tariff coefficient $\alpha_{3}$ is shown in Table 3. Indeed, estimates of the coefficient for the direct effects of tariffs on trade flows are reduced by roughly half when we leave out the competition index. This is consistent with a pattern across OECD importing countries where domestic retail

\footnotetext{
${ }^{3}$ The regions are: Australia; New Zealand; Rest of Oceania; China; Hong Kong; Japan; Korea; Taiwan; Rest of East Asia; Indonesia; Malaysia; Philippines; Singapore; Thailand; Vietnam; Rest of Southeast Asia; Bangladesh; India; Sri Lanka; Rest of South Asia; Canada; United States; Mexico; Rest of North America; Colombia; Peru; Venezuela; Rest of Andean Pact; Argentina; Brazil; Chile; Uruguay; Rest of South America; Central America; Rest of Latin America; Rest of the Caribbean; Austria; Belgium; Denmark; Finland; France; Germany; United Kingdom; Greece; Ireland; Italy; Luxembourg; Netherlands; Portugal; Spain; Sweden; Switzerland; Rest of EFTA (basically Norway); Rest of Europe; Albania; Bulgaria; Croatia; Cyprus; Czech Republic; Hungary; Malta; Poland; Romania; Slovakia; Slovenia; Estonia; Latvia; Lithuania; Russian Federation; Rest of Former Soviet Union; Turkey; Rest of Middle East; Morocco; Rest of North Africa; Botswana; South Africa; Rest of South African Customs Union; Malawi; Mozambique; Tanzania; Zambia; Zimbabwe; Rest of SADC; Madagascar; Uganda; Rest of Sub Saharan Africa
} 
cartels adjust their margins up as import tariffs are adjusted down, leading to a consistent underestimation of the direct impact of tariffs on trade (when holding distribution margins constant). If data were available, a suggested line of research involves matching movements in domestic retail and transport margins on imports with respect to variation in import tariffs.

\section{SUMMARY AND CONCLUSIONS}

The pattern of trade in goods depends on a number of factors. Recent work has stressed transport costs and its linkages to the geography of production and trade. We take a different slant here. In this paper we examine the interaction between trade in goods and the degree of market power exercised by the domestic trade and distribution sectors - the margin sectors. We first develop a theoretical model that allows us to highlight interactions between the degree of competition in service sectors, and the pattern of trade in goods. This is followed by an econometric exercise involving the import patterns of 21 OECD countries vis-à-vis 86 trading partners. Our theoretical results point to an expected linkage between service sector competition and goods trade. At least in theory, the domestic service sector can serve as an effective import barrier. This is also supported by our econometric results. These point to statistically significant linkages between effective market access conditions for goods, and the structure of the service sector. They also point to a qualitatively significant effect. Because of the implied interaction, at least across our sample of OECD countries, ignoring structure of the domestic service sector may lead to a substantial underestimation of the direct impact of tariffs on trade flows. 


\section{REFERENCES}

Breusch, T.S. \& A.R. Pagan (1979), A Simple Test for Heteroscedasticity and Random Coefficient Variation. Econometrica 47, 1287-1294.

Flam, H. and H. Nordström (1995), "Why Do Pre-Tax Prices Differ so much across European Countries," CEPR Discussion Paper No. 1181.

Feenstra, R.C. (2004), Advanced International Trade,, Princeton University Press.

Global Trade Analysis Project (2004), The GTAP Database version 6 (pre-release), GTAP consortium, Purdue University.

Huber, P. (1981). Robust Statistics. John Wiley \& Sons: New York, 153-199.

Hummels, D. (1999), “Towards a Geography of Transport Costs," mimeo, University of Chicago.

Lutz, M. (forthcoming), "Pricing in Segmented Markets, Arbitrage Barriers and the Law of One Price: Evidence from the European Car Market," Review of International Economics.

Nanto, N. (1998), “The Kodak-Fuji Film Trade Dispute at the WTO,” Congressional Research Service: Washington.

OECD (2000), "Regulatory Reform in Road Freight and Retail Distribution," paper ECO/WKP(2000)28, Paris.

Szroeter, J. (1978), "A Class of Parametric Tests for Heteroscedasticity in Linear Econometric Models," Econometrica 46: 1311-1327, 1978.

World Bank (2002), World Development Indicators, Washington DC. 
In this annex we develop the linear version of the model used for Figures 1 and 2 and equation (9.1) in the text. Equations (A.1), (A.2) and (A.3) define the export supply price $P$, the landed price $P^{L}$, and the consumer price $P^{d}$ in terms of tariffs $t$ and supply and demand coefficients.

$$
\begin{gathered}
P=a+b q \\
P^{L}=P T \quad T=1+t \\
P^{d}=x-y q
\end{gathered}
$$

From equations (A1)-(A3), the profit of an individual firm will depend on total equilibrium supply, tariffs, and the demand and supply coefficients.

$$
\pi_{i}=(x-y q) q_{i}-(T(a+b q)+c) q_{i}
$$

Applying symmetry, so that the number of firms is $n=\Omega^{-1}$, Cournot-Nash quantity competition yields equilibrium quantity.

$$
q=\frac{x-T a-c}{(1+\Omega)(y+T b)}
$$

Equation (A5) is reported as equation (9.1) in the text. Working with equation (A5), we can derive profit margins $\mu$ and profits $\pi=\mu q$ (by substitution into equation A4), consumer surplus (from equation A3), and tariff revenue $T R=(T-1) q$. 


$$
\begin{aligned}
T R & =\frac{(T-1)(x-T a-c)}{(1+\Omega)(y+T b)} \\
C S & =1 / 2 y \frac{(x-T a-c)^{2}}{(1+\Omega)^{2}(y+T b)^{2}} \\
\mu & =\frac{c+\Omega(x-T a)}{(1+\Omega)} \\
\pi & =\frac{(c+\Omega(x-T a))(x-c-T a)}{(1+\Omega)^{2}(y+T b)}
\end{aligned}
$$

Assuming that welfare maximization involves tariff revenue, consumer surplus, and (domestic) distribution sector profits, and that the service sector is perfectly competitive, the optimal tariff $T^{*}$ can be derived from equations (A6)-(A9).

$$
T^{*}=1+\frac{b(x-a-c)}{b(a+x-c)+a y}
$$

Alternatively, if the distribution sector is imperfectly competitive, the optimal tariff $T^{Z}$ can again be derived from equations (A6)-(A9).

$$
T^{Z}=\frac{(2 b-\Omega y)(x-c)+(1+\Omega) a y}{a[y+b(1-\Omega)]+(1+\Omega) b(x-c)}
$$

Figures 1 and 2 in the text are based on equations (A6)-(A11). 
FIGURE 1

WELFARE LEVELS, TARIFFS, AND COMPETITION IN THE DISTRIBUTION SECTOR

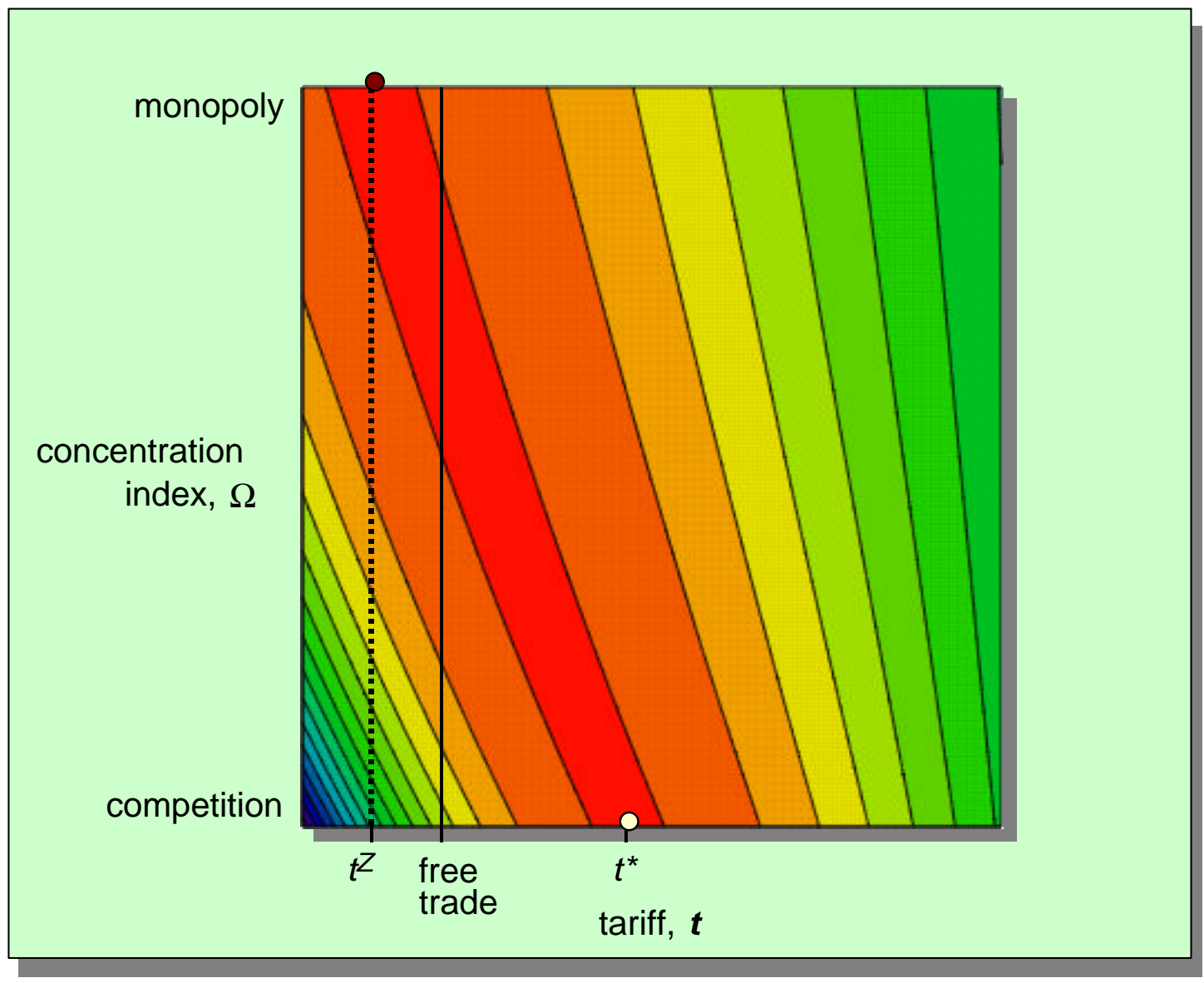

Note: Figure correspond to the linear supply and demand curves example developed in the appendix. 
FIGURE 2

DECOMPOSITION OF WELFARE IN THE CASE OF DUOPOLY $(\Omega=0.5)$

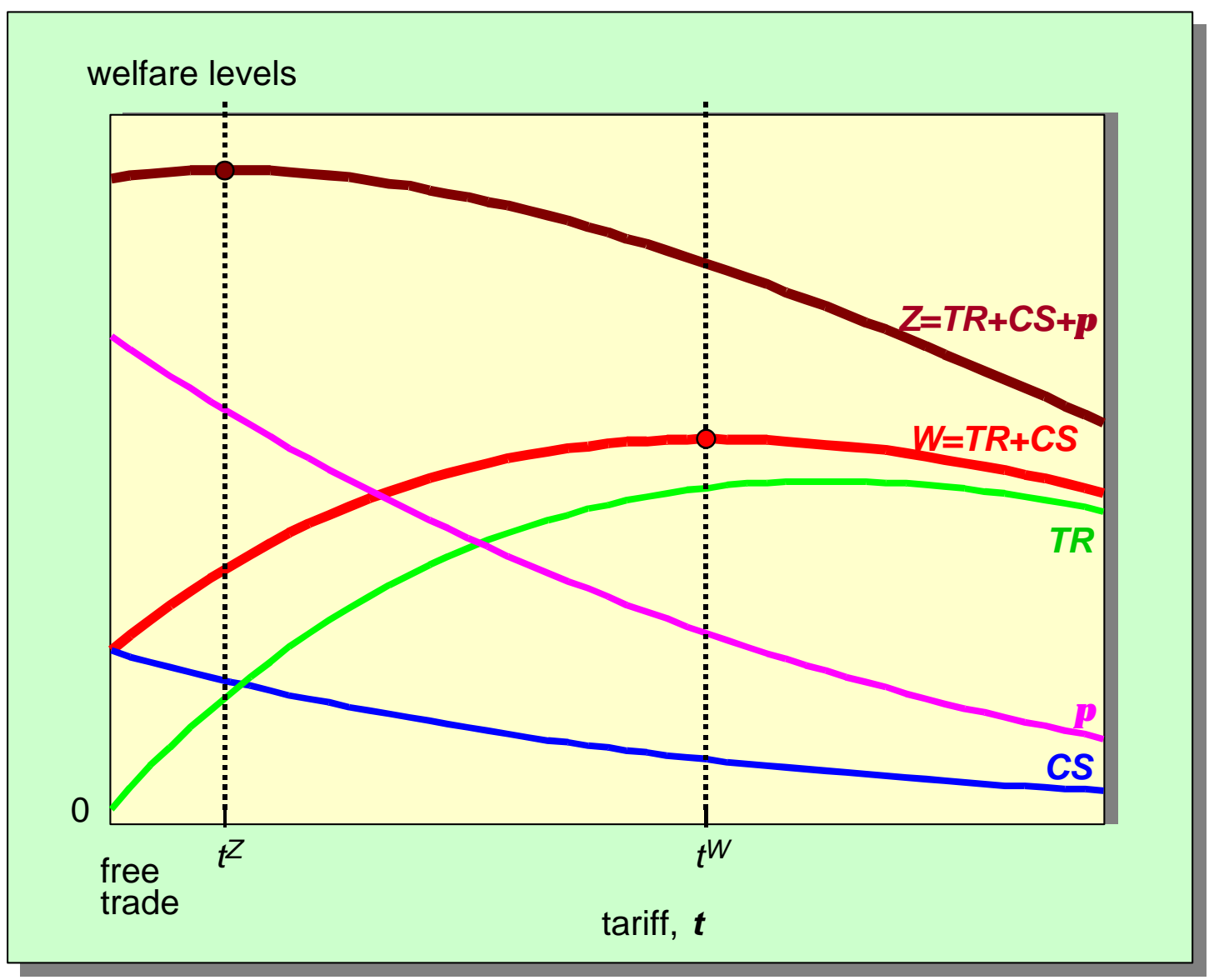

Note: Figure correspond to the linear supply and demand curves example developed in the appendix. 
TABLE 1, DATABASE OVERVIEW (VALUE DATA REPORTED IN LOGS)

\begin{tabular}{|c|c|c|c|c|c|}
\hline & & Mean & Median & Max & Min \\
\hline GDP & $\begin{array}{l}\text { importer gross domestic } \\
\text { product in billions of dollars in } \\
2001 \\
\text { Source: World Bank (2002). }\end{array}$ & 5.909 & 5.625 & 9.188 & 3.895 \\
\hline PCI & $\begin{array}{l}\text { PPP-based per-capita income, } \\
\text { dollars, } 2001 \\
\text { Source: World Bank (2002). }\end{array}$ & 9.989 & 10.108 & 10.442 & 9.017 \\
\hline Imports & $\begin{array}{l}\text { Millions of U.S. dollars in } \\
2001 \\
\text { Source: UNCTAD } \\
\text { COMTRADE and GTAPv6.2 } \\
\text { databases. }\end{array}$ & 5.109 & 5.310 & 12.084 & -2.168 \\
\hline $\begin{array}{l}\text { Tariffs } \\
\mathrm{T}=1+t\end{array}$ & $\begin{array}{l}\text { MFN trade-weighted tariff } \\
\text { (with adjustments for trade } \\
\text { preferences where available, as } \\
\text { reflected in concordance of } \\
\text { WTO, UNCTAD, and } \\
\text { MACMAPS tariff data } \\
\text { Source: GTAPv6.2 database }\end{array}$ & 1.054 & 1.028 & 2.324 & 1.000 \\
\hline $\begin{array}{l}\text { Transport } \\
\Gamma=1+g\end{array}$ & $\begin{array}{l}\text { ad valorem estimates of } \\
\text { bilateral transport costs for } \\
\text { traded goods, } \\
\text { all modes weighted by trade } \\
\text { Source: GTAPv6.2 database }\end{array}$ & 1.032 & 1.022 & 1.230 & 1.005 \\
\hline Index 1 & $\begin{array}{l}\text { Overall index of competition in } \\
\text { the retail/distribution sector } \\
\text { Source: OECD (2000) }\end{array}$ & 2.39 & 2.45 & 4.70 & 0.80 \\
\hline Index 2 & $\begin{array}{l}\text { Index of barriers to entry in the } \\
\text { retail/distribution sector } \\
\text { Source: OECD (2000) }\end{array}$ & 2.52 & 2.30 & 5.50 & 0.70 \\
\hline Index 3 & $\begin{array}{l}\text { Index of price flexibility in the } \\
\text { retail/distribution sector } \\
\text { Source: OECD (2000) }\end{array}$ & 1.80 & 2.10 & 4.00 & 0.10 \\
\hline
\end{tabular}

Note: The scale of competition indexes range from $0-6$, for least to most restrictive regimes. For countries reported as an interval by the OECD, the mid-point has been used. Countries for which index data are available are: Australia, Austria, Belgium, Canada, Czech Republic, Finland, France, Germany, Hungary, Ireland, Italy, Korea, Mexico, Netherlands, Norway, Poland, Portugal, Spain, Sweden, Switzerland, United Kingdom. Trade data are grouped by these 21 importers and by 86 exporting countries and regional groupings. Applied tariff data and transport costs data have been matched to these bilateral trade pairs. 
TABLE 2, OLS AND ROBUST REGRESSION ESTIMATES OF GRAVITY EQUATION OF TRADE

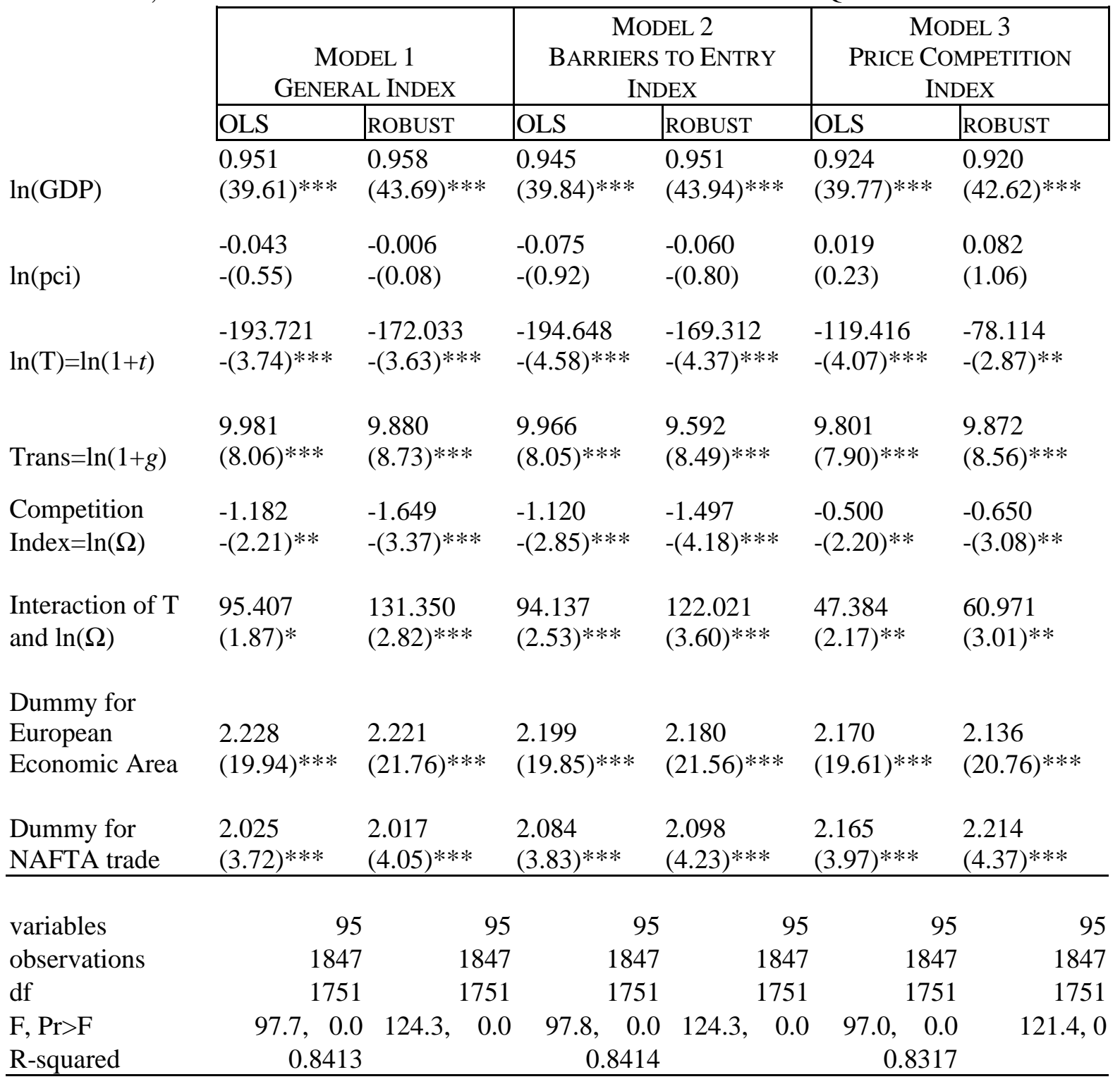

Breusch-Pagan

test statistic for

hetero-

skedasticity,

$\operatorname{Pr}>\mathrm{Chi} 2$

$281.0, \quad 0.00$

$278.0, \quad 0.00$

$261.8, \quad 0.00$

Significant hetero-

skedasticity by

Szroeter's test, .05

level

40 of 95

variables
41 of 95

variables
41 of 95

variables

Note: Robust regressions are estimating using Huber method as implemented in STATA, with default convergence criteria. $\mathrm{t}$ - statistics are reported in parentheses, with $*, * *$, and $* * *$ indicating .10, .05, and .01 levels of significance for a two-tailed test (or $.05, .025$, and .005 where a one-tailed test might instead be appropriate, as discussed in the text).

Heteroskadasticity tests are based on STATA implementation of the Breusch-Pagan/CookWeisberg test statistic and Szroeter's test statistic. 
TABLE 3, ESTIMATED TARIFF COEFFICIENT WITH AND WITHOUT INCLUSION OF COMPETITION INDEXES

\begin{tabular}{|l|l|l|}
\hline & $\begin{array}{l}\text { OLS } \\
\text { ESTIMATES }\end{array}$ & $\begin{array}{l}\text { ROBUST } \\
\text { ESTIMATES }\end{array}$ \\
\hline Model 1 & $\begin{array}{l}-193.721 \\
-(3.74)^{* * *}\end{array}$ & $\begin{array}{l}-172.033 \\
-(3.63)^{* * *}\end{array}$ \\
\hline & -194.648 & -169.312 \\
Model 2 & $-(4.58)^{* * *}$ & $-(4.37)^{* * *}$ \\
\hline & -119.416 & -78.114 \\
Model 3 & $-(4.07)^{* * *}$ & $-(2.87)^{* * *}$ \\
\hline Model without distribution & & \\
sector variables & -83.489 & -32.420 \\
& $-(2.77)^{* * *}$ & $-(1.17)$ \\
\hline
\end{tabular}

